\title{
JOSÉ BONIFÁCIO, HOMEM DE PENSAMENTO E HOMEM DE AÇÃO ( $\left.{ }^{\star}\right)$.
}

Ao aceitar o honroso convite do colendo Instituto Histórico e Geográfico de Santos para que eu participasse, na qualidade de um de seus oradores, das comemorações que promove em memória de José Bonifácio de Andrada e Silva, não deixei de advertir que eu não seria uma das vozes mais indicadas para trazer-lhes uma palavra nova a propósito da vida dêsse homem extraordinário, vida tão identificada com a existência mesma da nacionalidade. A despeito das referências tão generosas e lisonjeiras, mas evidentemente excessivas, com que me distinguiu o ilustre orador que acaba de apresentarme, o certo é que, nos estritos limites de meus estudos históricos e nas condições em que tenho exercido meu diuturno magistério, não me foi dada a oportunidade de orientar meus esforços especialmente no rumo da documentação arquival relativa ao Andrada insígne.

Nenhum brasileiro, entretanto, medianamente informado a respeito do tema, fugiria ao dever, se convocado a cumprí-lo, de prestar sua contribuição, por modesta que fôsse, à celebração do bi-centenário de nascimento dêsse herói nacional, em cujo vulto, um analista da envergadura de Gilberto Freire enxergou o maior de nossos estadistas, ou um historiador da lucidez e da probidade de Otávio Tarquínio de Souza encontrou o fundador por excelência do Império independente do Brasil! Eis porque estou desfrutando o privilégio de conviver, por algum tempo, com êste auditório de escol, ao atender à convocação dêste benemérito Instituto cujo amável convite tanto me tocou e que desejo desde logo agradecer, profundamente reconhecido.

A melhor maneira de festejar esta efeméride e perpetuar a memória de José Bonifácio consistiria na divulgação de documentos novos ou pouco difundidos. em tôrno de sua grande

(*). - Conferência pronunciada no Instituto Histórico e Geográfico de Santos em 4 de junho de 1963 (Nota da Redação). 
vida, obras e atividades. Estou persuadido de que uma prospecção cuidadosa nos arquivos de Portugal, França, Alemanha e Escandinávia, especialmente os das entidades públicas a que José Bonifácio serviu e os das sociedades científicas a que êle se filiou no Velho Mundo, para lembrar apenas êste campo de pesquisas, uma prospecção de tal ordem descobriria aspectos inéditos e relevantes de assunto histórico tão vasto e ainda não esgotado. Na impossibilidade de fazê-lo, fui buscar alguma inspiração na releitura do muito que já se escreveu sôbre José Bonifácio, perlustrando igualmente a documentação mais acessível aos estudiosos de São Paulo, a saber, os manuscritos pertencentes ao Patriarca e atualmente sob a guarda do Museu do Ipiranga. Ao rebuscar nessas fontes, certas reflexões preliminares me acudiram.

Atentei, primeiro, na perenidade de José Bonifácio, apesar das "revisões" contestáveis, tanto as obras de pêso e de indiscutível base documental, mas eivadas de paixão e parcialidade, como é o caso das interpretações de Varnhagen e Tobias Monteiro, quanto as simples "aventuras" de certos amadores da História, nomes mais ou menos esquecidos, que abordaram a matéria antes com uma espécie de mania da novidade ou com espírito de sensacionalismo jornalístico, que com a seriedade de autênticos pesquisadores. A verdade é que José Bonifácio permanece tão sòlidamente plantado em seu pedestal, de tal modo gravado na memória das gerações, que hoje se congregam os brasileiros, a dois séculos de distância do seu nascimento, para rememorar a grandeza humana e o insuperável papel do Patriarca, no movimento da Independência.

A seguir, ponderei que, ao empreender o estudo de um homem como José Bonifácio, logo percebe o pesquisador que se acha em face de uma dessas personagens capazes de forçálo a interessar-se, de não o deixar indiferente; personagem até perigosa, por assim dizer, porque pode inclinar o historiador a perder a serenidade, para solidarizar-se com as atitudes mais extremadas do biografado ou rebelar-se contra as mesmas, tão poderosa e atuante é a presença daquele homem, na dinâmica dos acontecimentos. Foi o que aconteceu a alguns historiadores que têm interpretado José Bonifácio, sem conseguir eścapar ao tom polêmico da parcialidade, assumindo a posição cientificamente inaceitável de "andradistas" e "nãoandradistas". O que cumpre evitar são os excessos do panegírico, bem como os desvios da catilinária, pois a veracidade das personagens nada tem a lucrar com semelhantes eqüívo- 
cos, mormente no caso de homens como José Bonifácio cuja grandeza acaba se impondo, "com a clareza dos fatos irrecusáveis", na frase de um de seus mais abalizados biógrafos (1).

Refleti, por último, na extensão do tema, tal a magnitude da personagem, a preeminência da atuação histórica de José Bonifácio, a projeção de sua poderosa individualidade nos acontecimentos da época em que viveu. Daí, a necessidade de circunscrever precisamente o assunto desta palestra, preferindo eu limitar-me a uma síntese em tôrno do homem de pensamento e do homem de ação que co-existiram em José Bonifácio, considerados um e outro à luz do seu caráter pessoal, ficando os acontecimentos no plano da perspectiva, para compor o campo em que as idéias se afirmaram e os atos se efetuaram.

$\mathrm{Na}$ evocação de um homem da configuração histórica de José Bonifácio, é natural que o perfil do estadista apareça em especial realce, por causa de sua atuação primacial, no movimento da independência. Por isso mesmo, costumam ficar um tanto esmaecidos os outros aspectos não menos ricos e sugestivos dessa personalidade excepcionalmente vigorosa e vária. Ora, a compreensão de um homem de tal porte, de suas ações e reações, de sua participação constante na vida que o rodeava, só ganhará em exatidão e clareza, se considerarmos a inteireza de sua complexa individualidade, no conjunto de suas virtudes e defeitos. E é o que procuraremos fazer, a começar pela formação intelectual de José Bonifácio.

A quem quer que se detenha no exame da bibliografia deixada por José Bonifácio e dos manuscritos que redigiu, de imediato se evidencia, como traço dominante de seu espírito, ao lado da prodigiosa fôrça intelectual, a universalidade da cultura. Homem de leis, filósofo e moralista, humanista e poeta, político e cientista, com a inteligência e a sensibilidade sempre voltadas para todos êsses domínios do conhecimento humano, acumulou José Bonifácoi um acervo de sabedoria e experiência do qual os seus contemporâneos, brasileiros e portuguêses, sequer puderam aproximar-se. Sua insaciável curiosidade de saber salta à vista, mal o estudioso começa a compulsar os manuscritos dêsse intelectual infatigável nos quais é verdadeiramente impressionante a variedade de assuntos em que êle se interessava: ciências naturais e paleontologia, arqueologia e epigrafia, história e política, geografia e viagens,

(1). - Otávio Tarquínio de Souza, José Bonifácio. José Olympio Editôra, São Pau10, 1945, p. 12 . 
cartografia e estatística, literatura e traduções poéticas, filologia e crítica, gramática moderna e greco-latina, economia e higiene, projetos de lei e atividades econômicas do Brasil. $\mathrm{Na}$ maior parte, êsses papéis não passam de esboços, planos, anotações rápidas, às vêzes tomadas em pedaços de papel sôlto e que em sua forma um tanto desordenada revelam aquela viveza e inquietude de temperamento que explicam, ao lado das circunstâncias desfavoráveis de sua vida, porque José Bonifácio nem sempre deixou obra escrita coerente e acabada, salvo as memórias científicas e os documentos políticos que pôde redigir metòdicamente.

Concluídos os estudos preparatórios, em sua província natal, José Bonifácio foi completar sua formação intelectual em. Coimbra, onde ingressou na famosa Universidade, já remodelada pela reforma pombalina de 1772 . Embora não atingindo - nível dos centros universitários europeus mais adiantados, a Universidade assim bafejada pelo sôpro modernizador da época, propiciou ao jovem estudante brasileiro os primeiros contactos com as novas correntes do pensamento europeu. Cursando as aulas de três Faculdades (Leis, Matemáticas e Filosofia), não se contentava com o que os mestres lhe ensinavam e devorava os livros mais representativos do tempo, os de seus autores prediletos que êle gostava de celebrar nos poemas de sua mocidade: pensadores políticos, como Voltaire a quem chamou "o vate dos filósofos", Locke, Montesquieu e Rousseau; poetas, como Pope e Virgílio, Camões e Horácio; os cientistas modernos: Leibnitz, Newton, Descartes. Essas leituras, meditadas e cotejadas com a realidade, como era do feitio de sua inteligência, também formada no cultivo das ciências naturais, essas leituras imprimiram no espírito de José Bonifácio a marca indelével da cultura setecentista, da Filosofia das Luzes, onde mergulham as raízes de sua concepção da sociedade orga-: nizada em bases racionais e de onde deriva também o seu ideá-: rio político, aparentado com a linha de pensamento do "despotismo esclarecido", a saber: a monarquia, como forma do Estado, mas em têrmos de liberalismo e constitucionalmente definida, com a finalidade do govêrno exercido em nome do "bem. público", ideal tão caro aos inovadores políticos do século XVIII.

O lastro teórico dessas idéias políticas foi completado pela fecunda experiência de suas viagens, através das quais José Bonifácio se pôs em contacto com os momentosos eventos da Revolução Francesa em marcha, com suas inovações e ex- 
cessos, e também com a aplicação das medidas reformadoras, em França e noutros pontos da Europa.

Discrepam os historiadores na apreciação das idéias políticas de José Bonifácio, oscilando as opiniões entre os extremos daqueles que o julgam um absolutista, ou quase, e de outros que chegam a considerá-lo próximo até do ideal republicano, se não pelo pensamento, ao menos pela índole democrática de seus sentimentos de justiça social, como é o caso dos positivistas que veneram o Patriarca. O julgamento exato há de encontrar-se nos escritos e no procedimento de José Bonifácio. Ouçamô-lo, em algumas afirmações pessoais. Da revolução de 1789 que se fêz precisamente para combater o absolutismo, pensava o seguinte: “...E por que quererão acabar hoje com as verdades que patenteou e inculcou a Revolução Francesa?"... "A Revolução Francesa foi a filha necessária do espírito do século cujo centro vital era Paris em tôda a Europa". E a propósito da instituição monárquica, sentenciou: "A Monarquia absoluta é, na realidade, uma aristocracia encoberta, e por isso tem todos os males do despotismo e da aristocracia..."; "...o melhor sistema de govêrno que o Brasil pode ter é a Monarquia temperada com instituições análogas às da Grã-Bretanha."

Quanto ao procedimento, os atos de José Bonifácio não desmentiram suas convicções: se o quisesse, poderia ter retardado, como poderoso Ministro que era, o decreto de convocação da Assembléia Constituinte, em 1822, mas concordou em assiná-lo, embora tivesse ponderáveis razões, que os fatos confirmaram, para temer que a medida fôsse prematura e inoportuna, no momento; bateu-se para que do Projeto de Constituição, elaborado na mesma Assembléia e que não chegou a ser votado, constasse, como constou, o preceito que criava condições para a "emancipação lenta dos negros e sua educação religiosa e industrial"; não aceitou especiais mercês, nem condição nobiliárquica, limitando-se a receber, por muita insistência de D. Pedro, o título e cargo modesto de Mordomo-Mor da Casa Imperial.

Portanto, nem absolutista, nem aristocrata. Cumpre não confundir a sinceridade de suas convições com os excessos que cometeu contra adversários políticos cuja atividade estava convencido de ser prejudicial à causa da independência. Em matéria de ideologia e de ação política, ficou José Bonifácio no meio têrmo, entre os áulicos partidários do absolutismo, de tendência retrógrada, e os liberais exaltados, o partido maçônico como dizia 
seu irmão Martim Francisco, partido de tendência republicana mal definida. "...Assim, no Brasil, escrevia êle, numa de suas notas autógrafas, nem os corcundas (isto é, os absolutistas), nem os demagogos (quer dizer, os liberais exaltados) quiseram convir com os constitucionais..." A designação final indica precisamente a posição intermediária que traduz a tendência monárquico-liberal de José Bonifácio e seus partidários. Aliás, nessas idéias e atitudes, como também nas idéias e projetos de ordem social e econômica, patenteia-se o espírito reformador, mas nada revolucionário do grande Ministro.

Sua opção pela Monarquia constitucional, como fórmula de organização política mais adequada ao Brasil de 1822, não se explica tanto em têrmos de preferência ideológica, mas em têrmos de compreensível oportunismo, no bom sentido da palavra; o Estadista sagaz tinha em mente que a Monarquia constitucional, com um poder central prestigioso e sólido, era o meio mais eficaz de consolidar a Independência, conciliando-a com o liberalismo e assegurando ao mesmo tempo a manutenção da unidade territorial e política do imenso país. Dessa maneira, o problema foi equacionado com realismo, sem compromisso com simples fórmulas ideológicas, sem prender-se apenas ao modêlo dos figurinos estrangeiros então na ordem do dia. Idéias mais minudentes sôbre a organização autonômica do Brasil, foram por êle fixadas nas Instruções que redigiu para uso dos Deputados brasileiros às Côrtes de Lisboa, em 1821. Mas, a Independência acarretava problemas da órbita internacional, sobretudo o reconhecimento da soberania brasileira e o perigo de uma tentativa de restauração portuguêsa, com apôio da Santa Aliança. Relativamente ao primeiro problema, coube a José Bonifácio apenas encaminhar-lhe a solução, mantendo os primeiros contactos com Londres, Washington e Paris, em meio às tremendas dificuldades internas que tinha de vencer, para consolidar o Império recém-fundado. A solução de uma questão fundamental ficou pelo menos esboçada: a supressão do tráfico negreiro, que a Inglaterra exigia como condição e que condizia com os ideais de José Bonifácio, relativamente aos escravos, seria feita gradualmente, para que não se perturbasse a produção econômica. E à direção dos negócios exteriores, o ardoroso Ministro imprimiu um cunho altivo que se traduz nesta assertiva dirigida a Chamberlain, o Encarregado de Negócios da Inglaterra: "O Brasil quer viver em paz e amizade com tôdas as outras nações. Há de tratar igualmente a todos os estrangeiros, mas jamais consentirá que êles intervenham nos 
negócios internos do país. Se houver uma só nação que não queira sujeitar-se a esta condição, sentiremos muito, mas nem por isso nos havemos de humilhar, nem submeter à sua vontade".

Antes, porém, de estabelecer relações diplomáticas com o Velho Mundo, José Bonifácio voltara as vistas para o Rio da Prata, onde procurou lançar a semente de uma política americanista que precedeu a chamada doutrina de Monroe. Política muito mais ampla que a delineada na famosa declaração do Presidente dos Estados Unidos, isolacionista mais do que panamericana, e cujas idéias essenciais se condensam na carta de José Bonifácio a Bernardino Rivadávia, de 10 de junho de 1822, e nas Instruções passadas a Correia da Câmara, enviado a Buenos Aires como cônsul e agente comercial, a saber: não apenas - resguardo da América contra possíveis investidas provindas do exterior, porém a união continental, num pacto de defesa dos territórios e dos interêsses comuns às nações do Novo Mundo, contra "as revoltantes pretensões da Europa".

Passando ao plano das idéias sociais e econômicas, é de surpreender não apenas a profundeza, mas também a originalidade e a coragem do pensamento de José Bonifácio, relativamente ao momento histórico em que êle proclamou tais idéias. Nos Apontamentos para a civilização dos Indios bravos ido Império do Brasil e na Representação à Constituinte sôbre a escravatura, traçou o lúcido e filantrópico conceito que, em tôrno da miserável condição das duas raças oprimidas, José Bonifácio foi pràticamente o único a sustentar. $\mathrm{Pa}$ ra êle, sem a extinção do regime servil e sem a assimilação do índio e do negro ao corpo social, o Brasil não poderia ser uma nação homogênea. Não podia o Estadista clarividente admitir a contradição que havia na coexistência de um povo livre e de uma socicdade estruturada com o trabalho escravo e com a marginalidade do indígena inculto. Vem a propósito lembrar a tese argutamente proposta, mas não desenvolvida por Joaquim Nabuco. Depois de assinalar que os legisladores do 2. Reinado, ao elaborar as leis abolicionistas, apenas cumpriram um dever, "sem amor, quase sem simpatia" pelo escravo, em contraste com a profunda solidariedade e o sentido humanitário que animam a Representação de José Bonifácio, indaga o historiador até que ponto as idéias do grande Ministro sôbre a escravidão, idéias tão contrárias aos interêsses da aristocracia rural dos senhores de escravos, concorreram para que êle fôsse apeado do poder e bruscamente se encerrasse 
sua carreira política. O tema está para ser educidado. Uma coisa, porém, é certa: o Ministro que não titubeava em apontar os males sociais e econômicos do latifúndio e em preconizar a abolição da escravatura, não podia contar com a simpatia, menos ainda com o apôio político dessa aristocracia dominante e dos comerciantes portuguêses que se locupletavam com o tráfico negreiro.

A largueza das idéias econômicas de José Bonifácio nada ficava devendo à amplitude de seu pensamento político e social; essas idéias são igualmente reveladoras daquela acuidade e caloroso interêsse com que êle se habituara a refletir sôbre as realidades do Brasil. Assinalou o baixo rendimento do trabalho servil, como decorrência da ignorância e incapacidade técnica do escravo, em geral propenso à indolência . Clamou contra o latifúndio do qual, a seu ver, resultavam graves inconvenientes: a existência de vastas glebas incultas que apartavam as povoações sertanejas umas das outras, condenando-as ao isolamento em que vegetavam e se embruteciam. Advogou, por isso, uma nova legislação sôbre sesmarias, para que se reincorporassem à massa dos bens nacionais as terras incultas, e fôssem redistribuídas, não a título gratuito, mas por venda e em lotes médios e pequenos (meia légua quadrada no máximo); essa reforma da propriedade fundiária, seria completada por medidas conducentes à efetiva colonização e cultivo das terras, à preservação de matos e arvoredos, à prática do reflorestamento, ao uso equitativo das aguadas. Em suma, as linhas gerais de uma reforma agrária de verdade, meditada à luz das realidades da época, a qual, na simplicidade de sua síntese, compreende aspectos que hoje ainda não perderam a atualidade.

Esmiuçou também José Bonifácio as possibilidades produtivas do Brasil, em vista da exportação, sentindo a importância da expansão do comércio exterior, para a prosperidade e consolidação econômica de um país como era o nosso, sem possibilidades industriais imediatas e ainda prêso à produção agrária. E numa pequena página manuscrita, cuja leitura chega a ser comovente, enumerou os produtos que êle julgava exportáveis, desde o café e o algodão até a simples vela de sêbo. Outros problemas ainda, que seria longo mencionar, estavam presentes àquêle espírito infatigável, como atestará a simples leitura dos apontamentos e projetos que deixou sôbre a matéria. 
Todavia, nas Instruções de 1821 aos Deputados brasileiros, já lembradas, o problema da educação e cultura precedia as considerações de ordem econômica, e se apresentava diretamente ligado à manutenção do sistema político. Sustentava aquêle documento que não pode haver "govêrno algum constitucional que dure, sem a maior instrução e moralidade do povo". São a seguir preconizadas as medidas práticas que pareciam indispensáveis a José Bonifácio: criação de escolas de primeiras letras em tôdas as cidades, vilas e freguesias; em cada Província, um ginásio ou colégio para o ensino das ciências úteis, e mais as cadeiras de medicina, cirurgia e veterinária, matemática, física e química, botânica e horticultura, zoologia e mineralogia; e, coroando o edifício, pelo menos uma Universidade, a sonhada Universidade para cuja direção D. João VI se lembrara exatamente de José Bonifácio, mas que não existiria antes do século XX.

Mutilada ficaria esta síntese da personalidade intelectual de José Bonifácio, se deixássemos de considerar, ainda que sumáriamente, dois outros aspectos: o cientista e o poeta. Como homem de ciência, recebera êle sólida formação teórica, em suas viagens de estudos, iniciadas em 1790 e durante as quais ouviu as lições de Química e Mineralogia dos mais abalizados mestres da época. Passando à prática, assentou praça de mineiro em Freiberg, trabalhando na indústria local, e desceu às entranhas das minas do Tirol, da Caríntia, da Boêmia e da Noruega. Trouxe sua notável contribuição ao domínio das descobertas científicas: achado de quatro espécies minerais novas e de oito variedades de espécies já conhecidas que êle descreveu pela primeira vez. Descobertas que o faziam merecedor de estátuas em seu país, na opinião do francês Le Play, e que lhe abriram as portas de várias das mais célebres sociedades científicas da Europa. Mas, embora continuasse suas investigações e publicasse suas memórias científicas, a universalidade de seu espírito o alertava contra os riscos de uma especialização exagerada, capaz de amortecer-lhe a imaginação e a sensibilidade; por isso, não abandonou a leitura metódica dos mestres da literatura antiga e moderna .

Aliás, em seu amor à natureza, o interêsse do cientista fundia-se com os pendores de poeta. Podia êle fechar uma página de sua Memória sôbre o plantio de novos bosques em Portugal, com estas belas palavras: “...Demais, sem bastante umidade não há prados; sem prados, pouco ou nenhuns gados; e sem gados, nenhuma agricultura. Assim, tudo é ligado 
na imensa cadeia do Universo; e os bárbaros que cortam e quebram seus fuzis, pecam contra Deus e a Natureza, e são os próprios autores de seus males".

Em José Bonifácio, o poeta está longe de ombrear com o sảbio e o estadista. No entanto, sua obra poética interessa pelo que desvenda a respeito do homem, de sua intensa vida interior e até de suas paixões políticas. Para êle, a poesia foi antes de mais nada um veículo do pensamento, e suas estrofes de conteúdo político (Ode aos Gregos, Ode aos Baianos) atestam o nobre conceito em que êle tinha a arte poética, como alta expressão das idéias. Essa poesia, ainda que excessivamente acadêmica e um tanto fria na forma arcádica que trai mais uma influência do século XVIII, ajuda-nos, contudo, a penetrar a sensibilidade que inclinava José Bonifácio a contemplar com olhos extasiados as belezas naturais e os encantos da vida exterior.

Entretanto, essa opulência de idéias não o reduziu a um homem de gabinete e de laboratório. Se nêle havia o homem de pensamento, votado ao culto das ciências, das letras e da filosofia, havia também o homem de ação, preocupado com o alcance prático das obras que empreendia. Essa dualidade se revela quer no campo da especialização científica, onde pôs o seu cabedal de sábio a serviço de obras de utilidade pública, quer no campo da política, já como homem de pensamento, meditando na organização do Estado brasileiro, já como homem de govêrno, enfrentando os problemas imediatos e para os mesmos encontrando soluções adeqüadas. A capacidade de agir e decidir, com lucidez e presteza, possibilitou a José Bonifácio tomar prontamente as medidas governamentais necessárias para consolidar a Independência, após o Fico, tanto as de natureza político-administrativas, como as de caráter militar, destinadas a extinguir os focos de resistência, nas províncias que ainda não gravitavam em tôrno do govêrno central.

Entre os tipos de heróis que estudou através da História, Sidney Hook definiu o tipo do "event-making man", 0 homem capaz de gerar os acontecimentos, não pela capacidade de criar sòzinho as condições históricas em que os fatos se desencadeiam, mas porque imprime o sêlo de sua energia e inteligência a êsses mesmos fatos. Tal é o caso de José Bonifácio, e por isso, um historiador do agudo senso crítico de Oliveira Lima viu no genial santista o nome mais representativo do movimento da independência, acrescentando que calar o no- 
me de José Bonifácio, "quando se trate da nossa emancipação política, seria o mesmo que falar da Reforma sem mencionar Lutero, ou recordar o Ressurgimento, escondendo Cavour".

Em seus atos públicos, punha José Bonifácio tôda a fôrça de seu temperamento afirmativo. Nas posições de mando que ocupou - e raramente não estêve em tal posição - êsse homem autoritário por natureza foì a própria encarnação da autoridade, em política, na administração, no magistério, no comando do batalhão acadêmico de Coimbra, durante a resistência contra os invasores franceses de Portugal. Orgulhoso, além de autoritário, mas de um orgulho que era ditado não por vaidade fútil, e sim pelo brio de seu caráter e pela consciência do próprio valor. A êste respeito, é muito elucidativa a passagem que, mesmo sendo puramente anedótica, ajusta-se bem ao feitio de José Bonifácio e nô-lo mostra em palestra com um inglês; querendo êste lisonjear o brasileiro, perguntou-lhe com a perfeita arrogância de um súdito de Sua Majestade Britânica: - Tendes a honra de ser inglês? Ao que José Bonifảcio retrucou ao pé da letra: - Tenho a honra de o não ser!

Impulsivo, além de autoritário e orgulhoso, chegou a cometer alguns erros, como homem de govêrno, erros a que nunca foi movido por motivos subalternos e que derivaram não só de seus ímpetos, mas também da incompreensão, da intolerância e da vaidade de seus adversários. A lucidez de sua inteligência, a sua superioridade moral o levaram a dar-se conta de tais excessos do temperamento férvido com que nascera, para repetir suas mesmas expressões. "O céu me dotou de uma alma tôda de fogo para defender a honra e os sentimentos que podem enobrecer minha existência...", afirmou êle numa dessas notas auto-biográficas em que o sábio denota sua preocupação de definir-se e defender-se de suas próprias paixões. Dessa tendência, provieram suas numerosas máximas de moralista e umas regras de comportamento, no final das quais escreveu esta auto-advertência:

"Homem impetuoso e desregrado, lê todos os dias e tôdas as vêzes que te devas apresentar ante gente estas lembranças, e acostuma-te a regular-te por elas".

Homem extrovertido e entusiasta, que nunca se omitiu, quando e onde quer que seu concurso fôsse reclamado, muitas vêzes José Bonifácio se viu em conflito com o meio ao qual era acentuadamente superior. Assim aconteceu em Portugal, onde a falta de recursos, a rotina, a burocracia, a incompreensão o impediram de exercer eficazmente as múltiplas funções 
que lhe foram atribuídas. Eis aí uma das razões determinantes de seu regresso ao Brasil, onde se repetiu o drama, quando as circunstâncias o lançaram na política, sem que êle o desejasse, numa das fases mais criticas de nossa História.

As condições em que, então, ocupou o poder, com a premência dos problemas políticos e militares que tinha de resolver, deram-lhe margem para tornar-se o Patriarca da Independência, quer dizer, o condutor por excelência do seu povo, na conquista da emancipação nacional; mas, não lhe permitiram que pusesse o vasto saber e o claro tirocínio na execução das grandes reformas que planejara. Assim mesmo, o pouco que conseguiu fazer comprova a perfeita coerência entre suas idéias e seus atos, sempre que pôde agir com liberdade e severidade. Assim foi, por exemplo, na decretação de medidas concretas para defesa e proteção dos índios, na Província do Espírito Santo. Não menos coerente com sua maneira de pensar, foi o procedimento de José Bonifácio, ao dispensar o concurso do braço escravo para arrotear a quinta que arrendara perto de Coimbra, e depois o seu sítio dos Outeirinhos, em terra santista. A inteira veracidade e o fascínio da personalidade de José Bonifácio ficarão falseados, se o reduzirmos às proporções de ídolo monumental ou de herói comemorativo, se apresentarmos apenas como o Estadista inatingível ou frio filósofo, encarcerado na impassibilidade da sabedoria, obscurecendo ou calando os outros aspectos que o configuram como criatura profundamente humana que foi, com uma imensa alegria de viver...

Outros aspectos dessa fascinante personalidade completam a configuração de José Bonifácio como criatura profundamente humana que foi: a alegria de viver que não arrefeceu, mesmo nos momentos conturbados; o prazer da leitura e do estudo que se revigorou no exílio do "ermitão de Talance", como êle mesmo gostava de denominar-se; o gôsto dos costumes simples e aquela capacidade de atrair a convivência de amigos moços, como o fidelíssimo Vasconcelos de Drummond, o divulgador das preciosas Cartas Andradinas.

Quero destacar apenas, e para concluir, o profundo brasileirismo de José Bonifácio, a despeito dos longos anos passados na Europa, apartado do seu querido torrão santista. Esse sentimento, tão visceral em José Bonifácio, foi admiràvelmente salientado por Latino Coelho, o seu biógrafo português, e se traduziu eloqüentemente em alguns pensamentos e lances de sua vida. "Os políticos da moda, escreveu êle, querem que - Brasil se torne Inglaterra ou França; eu quisera que êle não 
perdesse nunca os seus usos e costumes simples e naturais, e antes retrogradasse que se corrompesse". Reencontrando-o no Brasil, o mineralogista Von Eschwege que o conhecera em Portugal, admirou-se de ver José Bonifácio dansando magistralmente um lundú bem brasileiro, numa alegre reunião familiar em casa do Andrada, com muita conversa, música e canto. E outra pitoresca manifestação dêsse brasileirismo encontra-se no bilhete que êle dirigiu a seu caro amigo Vasconcelos de Drummond e cujos deliciosos têrmos não me furto ao prazer de repetir-lhes:

\section{Nhonhô Antônio}

Eu fico sòzinho hoje em casa; se mecê, meu sinhozinho de França, prefere comer pirāo com toucinho à Paulista aos quitutes do grandiosíssimo Sr. D. Luís de las Panreas, cá o espero; se não, Deus ajude a mecê.

Seu muleque Andrada.

Assim era ainda, depois de quase seis anos de atribulado exílio, o ânimo dêsse homem já bem mais que sexagenário, mas que soube conservar-se môço de espírito e manter aquela personalidade inteiriça e indeformável que nem a idade, os encargos; as fadigas e os sofrimentos puderam alterar sensivelmente.

Tempo é de finalizar, que não desêjo abusar da paciência dos que me dão a honra de ouvir.

Muitos são os títulos que ilustram os Anais desta nobre cidade de Santos, há mais de quatro séculos presente nas páginas da História Pátria, desde os seus alvores, em solo paulista: baluarte avançado, a princípio, contra a hostilidade da indiada rebelde e da corsaria estrangeira; ponto de apôio, em seguida, para a penetração civilizadora, além das abruptas encostas da serrania, em terras do planalto de Piratininga; elo econômico a articular as correntes externas da importação com as da produção exportável do interior, desde a época colonial até os nossos dias; em suma, um dos focos inaugurais e geradores de nossa prosperidade, cultura e tradição.

Pois bem, nesta semana votiva do "Ano do Patriarca da Independência", conforme a denominação estatuída em recente lei da Municipalidade santista, a cidade que tem o privilégio de ser o bêrço de José Bonifácio, conquista ao Brasil mais um título de gratidão mercê da grandeza, eloqüência e gene- 
rosidade que vem sabendo emprestar às comemorações consagradas ao maior de seus filhos.

Honra, pois, a Santos, à sua Municipalidade e a seu Instituto Histórico, minhas Senhoras e meus Senhores, honra a Santos, a cidade de José Bonifácio!

RAUL DE ANDRADA E SILVA

Instrutor da Cadeira de História da Civilização Americána da Faculdade de Filosofia, Ciências e Letras da Universidade de São Paulo. 